\title{
麻痺側立脚期に膝関節が伸展する片麻痺者の 歩行時の足関節筋活動の分析
}

\author{
Analysis of Ankle Muscle Activities During the Extension Thrust \\ of Hemiparetic Patients Gait
}

田中 惣治 ${ }^{1,2)}$ 山本 澄子 ${ }^{2)}$

\author{
SoJI TANAKA ${ }^{1,2)}$, SUMIKo YAMAMOTO ${ }^{2)}$ \\ 1) Department of Rehabilitation, Nakaizu Rehabilitation Center: 1523-108 Hiekawa, Izu-shi, Shizuoka 410-2527, Japan. \\ TEL+81 558-83-2203 E-mail: umbobo_souji@hotmail.com \\ 2) Department of Assistive Technological Science, International University of Health and Welfare, Graduate School
}

Rigakuryoho Kagaku 29(6): 873-876, 2014. Submitted Apr. 28, 2014. Accepted Jun. 27, 2014.

\begin{abstract}
Purpose] The ankle joint muscle activities during gait of hemiplegics exhibiting a nearly normal knee pattern (NKP) and the extension thrust pattern (ETP), in which the knee extends in the stance phase of the hemiplegic side, were analyzed. [Subjects and Methods] The subjects were 14 hemiplegic patients in the recovery stage, and the activities of their hemiplegic side tibialis anterior (TA) and gastrocnemius (Gas) muscles were measured in the stance phase of the hemplegic side during gait at a self-selected speed. [Results] In the NKP, activity of TA in the loading response phase was significantly greater than in the single-leg support phase, but in the ETP no significant differences in TA were found during the stance phase. No significant differences in Gas activities were found in the stance phase of either group of subjects. [Conclusion] The results suggest the possibility that in the stance phase of the hemiplegic side, TA activity is a factor contributing to knee extension during the loading response phase of the hemiplegic side.
\end{abstract}

Key words: hemiplegia, gait, muscle activity

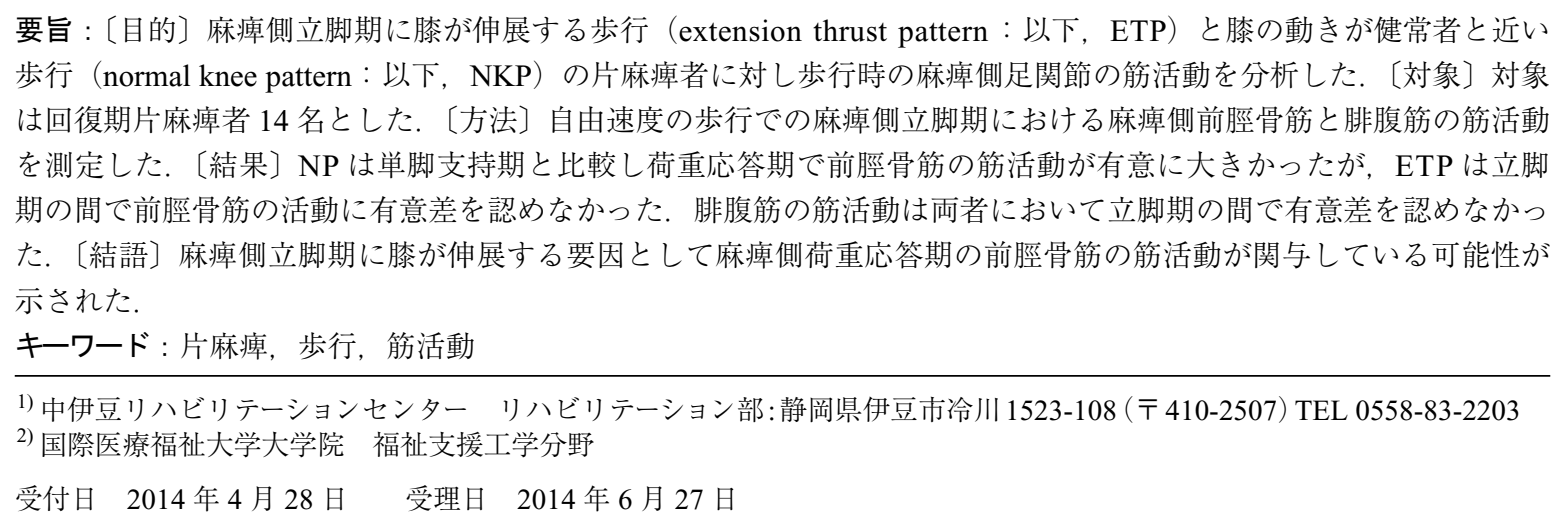




\section{I. はじめに}

片麻痺者の歩行分類に関する研究で, de Quervain ${ }^{1)}$ は 麻疩側立脚期に膝関節が伸展する歩行 (extension thrust pattern：以下，ETP）が主に低速度歩行の患者で認めら れることを報告している。臨床においてもETP は非常 に多くみられることから, ETP は片麻疩者の歩行の特 徵のひとつと言える. 先行研究では立脚期の膝関節の動 きで分類した歩行パターンと股・膝関節の筋活動に関係 はなかったと報告されているが1-3), Mulroyら4) は発 症早期の片麻疩者の歩行において麻瘒側下肢の筋活動の 低下がみられ，特に立脚期で足関節底屈筋の活動が不十 分となり下腿の制御がそしくなることで膝伸展が生じる としている。 また, Lamontagne ら5) は片麻疩者の歩行 時の前脛骨筋と腓腹筋の筋活動から同時収縮の程度を調 査し, 非麻痺側と比較し麻痺側単脚支持期で同時収縮が 減少することを確認し, 立脚期の不安定性を反映してい ると報告している。よって, 片麻疩者の歩行には麻瘏側 足関節周囲筋の筋活動の変化が影響しており, これが立 脚期の膝関節の動きを決める要因の一つと考えられるが, その詳細は明らかになっていない. そこで本研究では片 麻疩者の歩行を立脚期の膝関節の動きで分類し, 歩行時 の麻痺側足関節の筋活動を比較した。

\section{II. 対象と方法}

\section{1. 対象}

対象は脳損傷片麻疩者 14 名（男性 12 名, 女性 2 名, 年齢 $54.4 \pm 12.4$ 歳, 身長 $167.4 \pm 6.9 \mathrm{~cm}$, 体重 $69.9 \pm$ $12.8 \mathrm{~kg}$, 発症からの日数 $91.9 \pm 41.7$ 日）である. 本研 究における片麻瘏者の選定条件は, 短下肢装具の装着な しで歩行が可能な者（杖などの歩行補助具の使用は問わ ない), 足関節背屈可動域が他動で $0^{\circ}$ 以上, 高次脳機能 障害が重度でない者（口頭指示に対する理解が可能）, 失調症状がない者, 表在・深部感覚が脱失していない者,
整形外科疾患や歩行に障害を及ぼす合併症を有さない者 とした。歩行分類は先行研究に準じ，目視により麻疩側 立脚期の膝の動きで分類した ${ }^{1)}$. 本研究ではETP が 8 名 (以下, ETP 群), 対照として健常者の歩行時の膝関 節の動き近い正常膝パターン（normal knee pattern: 以下 NKP 群）が 6 名であった（表 1)。なお，年齢，身長， 体重, 発症からの日数, 下肢 BRS, 足関節底屈筋 MAS に，両群間で有意差はみられなかった。

対象者には研究内容と方法について口頭および書面に て十分に説明を行い，書面にて同意を得た。なお，本研 究の内容は国際医療福祉大学倫理委員会（承認番号 11-47）にて承認を得た

\section{2. 方法}

計測は直線 $10 \mathrm{~m}$ の歩行路における対象者の自由速度 歩行とした。筋活動の測定はマルチテレメータシステム WEB-5500 (日本光電社製) を用い, サンプリング周波 数は $2 \mathrm{kHz}$ とした。被験筋は麻疩側前脛骨筋と腓腹筋外 側頭（以下，腓腹筋）の 2 筋とした。電極貼付位置は SENIAM (Surface ElectroMyoGraphy for the NonInvasive Assessment of Muscles）が推奨する位置を参考 にした ${ }^{6}$ ．筋電位の検出には直径 $1 \mathrm{~cm}$ の双極表面電極 を用い, 電極間距離は $1.5 \sim 2 \mathrm{~cm}$ の範囲内に定めた。電 極装着時は電極抵抗を少なくするためアルコールおよび スキンピュア (日本光電社製) で表面の角質層および脂 肪分を除去し, 十分な処理を行った。

歩行の相分けと歩幅の分析のためデジタルビデオカメ ラ（SONY 社製 CVX-560）を使用し，対象者の麻疩 側矢状面から歩行を撮影した。 デジタルビデオカメラは 三脚上に取り付け，被写体からの距離は $4.5 \mathrm{~m}$ とし, カ メラの高さは床面からレンズの中心までの距離を $0.95 \mathrm{~m}$ とした。撮影した映像データは動画解析ソフト DART FISH Software Pro5.5（DART FISH 社製）を使用 して, 麻痺側の初期接地, 非麻痺側のつま先離れ, 非麻 瘒側の初期接地, 麻瘏側のつま先離れのタイミングをそ

表 1 対象者の情報

\begin{tabular}{|c|c|c|}
\hline & $\mathrm{NKP}$ 群 $* 1$ & ETP 群 $* 2$ \\
\hline 年齢（歳） & $(12.1)$ & $(13.4)$ \\
\hline 身長（cm） & 171.2 & 164.5 \\
\hline 体重（kg） & $(10.5)$ & $(14.4)$ \\
\hline 発症からの日数（日） & $(41.4)$ & $(44.8)$ \\
\hline 麻痺側（人） & 右 : 3 , 左 : 3 & 右: 3 , 左 : 5 \\
\hline 診断名（人） & 脳出血 : 2 , 脳梗塞 : 4 & 脳出血 : 4 , 脳梗塞 : 4 \\
\hline 下肢 BRS (人) $* 3$ & III $: 2, \quad \mathrm{~V}: 2, \quad \mathrm{VI}: 2$ & III $: 2, \quad$ IV $: 4, \quad$ VI $: 2$ \\
\hline 足底屈筋 MAS (人) $* 4$ & $1: 2,1+: 3,2: 1$ & $1: 4,1+: 3,2: 1$ \\
\hline
\end{tabular}

数值は平均值（標準偏差）で表示. ${ }^{* 1} \mathrm{NKP}$ 群 $=$ normal knee pattern 群, *2 ETP 群 = extension thrust pattern 群, ${ }^{* 3} \mathrm{BRS}=$ Brunnstrom recovery stage, ${ }^{* 4} \mathrm{MAS}=$ modified Ashworth scale. 
表 2 NKP 群と ETP 群の筋活動

\begin{tabular}{|c|c|c|c|c|c|c|}
\hline & & & 前脛骨筋 & & & 腓腹筋 \\
\hline & LR & 146.3 & (121.9-166.4) & & 96.3 & $(90.7-102.4)$ \\
\hline NKP 群 & SS & 55.9 & $(53.7-75.0)$ & & 121.4 & $(112.1-139.4)$ \\
\hline & PSw & 94.4 & $(61.4-122.9)$ & & 119.3 & (111.6-130.2) \\
\hline & LR & 100.4 & $(92.7-105.5)$ & & 114.7 & $(101.8-130.7)$ \\
\hline ETP 群 & SS & 94.0 & $(84.9-100.7)$ & & 106.8 & $(104.9-122.0)$ \\
\hline & PSw & 95.5 & (91.4-99.9) & & 99.3 & $(93.7-100.8)$ \\
\hline
\end{tabular}

表記は中央值 (四部位範囲). $*$ : $p<0.05$.

れぞれ抽出した。これから，麻痺側立脚期を荷重応答期 (loading response : 以下, LR), 単脚支持期 (single stance : 以下, SS), 前遊脚期 (pre swing : 以下, PSw) の 3 つに相分けした。映像データのサンプリング周波数 は $60 \mathrm{~Hz}$ に設定した。 DART FISH から麻痺側・非麻痺 側の歩幅を算出し, 対象者の身長で正規化した（歩幅/ 身長 $\times 100 ）$ 後， 5 歩行周期の平均を算出した。筋電図 データと映像データとの同期を取るため, 計測開始直後 にLED ランプによるトリガー信号を入力した．歩行時 の筋電図信号は筋電用増幅器 (日本光電社製) で $0.5 \mathrm{mV} / \mathrm{diV}$ に増幅し, A/D 変換して筋電解析用パーソ ナルコンピュータに取り込んだ，得られた筋電図信号の 解析には，WEB-5500 (日本光電社製) を使用し 10 か ら $300 \mathrm{~Hz}$ のバンドパスフィルターをかけた後, 自乗平 均平方根 (root mean square：RMS）を求めた。次に, 各筋毎に 1 歩行周期の筋活動の RMS の平均を求め, こ れを $100 \%$ として各相の RMS の平均值をそれぞれ正規 化した。さらに，5歩行周期分のデータを抽出した後, 歩行パターン毎に LR, SS, PSwの筋活動量を比較した.

統計処理に関しては統計処理ソフト Rを使用し，各 相の筋活動の比較は Friedman 検定を行った後, 多重比 較検定を用いた。また，麻痺側と非麻瘏側の歩幅の比較 はWillcoxonの符号付順位和検定を用いた。各統計処理 の有意水準は $5 \%$ 未満とした。

\section{III. 結果}

筋活動に関して, NKP 群では SS と比較し LR で前脛 骨筋の筋活動が有意に大きかったが，腓腹筋は各相の間 で有意差を認めなかった（表 2)，ETP 群においては前 脛骨筋，腓腹筋ともに各相の間で有意差を認めなかった (表 2).

歩幅に関して，NKP 群では麻瘏側と非麻痺側の歩幅 に有意な差は認めなかったが, ETP 群では非麻痺側の 歩幅が有意に小さかった（表 3 ).
表 3 NKP 群と ETP 群の歩幅

\begin{tabular}{|c|c|c|c|c|}
\hline & NKP 群 & & ETP 群 & \\
\hline 麻痺側 & $28.6(25.7-32.2)$ & 24.6 & $(23.5-26.7)$ & \\
\hline 非麻痺側 & $29.3(25.8-32.0)$ & 18.0 & $(10.2-23.6)$ & * \\
\hline
\end{tabular}

表記は中央值（四部位範囲）。 $*$ : $<<0.05$.

\section{IV. 考察}

健常者歩行では接地後の LR に前脛骨筋の活動が大き くなり，単脚支持期に腓腹筋の筋活動が最大となる 7 ). 大畑は ${ }^{8)}$ 歩行についての力学的なパラダイムである「倒 立振子」を振るための機能として踵ロッカー時に前脛骨 筋が働き, 底屈運動と同時に下腿を前傾させることで推 進力を形成するとしている。

本研究においては，NKP 群では前脛骨筋の筋活動が LR で大きくなり, 麻痺側と非麻痺側の歩幅が同程度に 大きかった。 これより，NKP群は健常者と同様に，踵 ロッカー時の前脛骨筋の活動により倒立振子の初速を得 ることができ, 重心の前方移動が行えていると考える. 一方, ETP 群は立脚期の前脛骨筋の活動に相の間で差 を認めず，LR で前脛骨筋の活動を大きくすることがで きなかった。つまり，踵ロッカー時の下腿を前方に移動 させる前脛骨筋の活動が十分には得られず，下腿が後傾， すなわち膝が伸展したと考える。また，ETP群は麻痺 側と比較して非麻痺側の歩幅が小さかったことから，倒 立振子の推進力を得られず, 重心の前方移動が行えない と考えられる.

腓腹筋の筋活動は NKP 群と ETP 群において立脚期の 間で差を認めず，健常者のように SS で筋活動を高める ことができなかった，多くの研究で片麻疩者の歩行の特 徵として, 立脚後期の足関節モーメントの低下と底屈筋 筋活動の低下が報告されている9,10). 本研究の NKP 群 は健常者の膝の動きが正常に近いパターンであるが, SS に腓腹筋の活動を大きくすることは難しく，底屈筋の筋 活動低下は片麻痺者に共通した現象といえる。また, Perry ${ }^{11)}$ は膝の伸展が過剩にみられる現象の理由の一つ 
として底屈筋の症性麻㾝や拘縮に対する代償と説明して いるが, 本研究の対象者では足関節背屈可動域制限は認 められず，NKP 群と ETP 群間においても足関節底屈筋 の筋緊張に差は認められなかった。 よって, 麻痺側立脚 期に膝が伸展する要因としては, 足関節底屈筋の筋緊張 や拘縮, 歩行時の腓腹筋の筋活動だけでなく，麻瘏側 LR の前脛骨筋の筋活動も関与している可能性が示され た.

本研究の限界として対象者数が少ないことが挙げられ る. 今後は麻痺側立脚期の膝関節の動きで分類した歩行 パターン別に被験者数を増やし検証する必要がある。今 回は歩行時の麻痺側足関節の筋活動のみに着目し, 前脛 骨筋の筋活動に一定の傾向を認めたが, 麻痺側膝・股関 節の筋活動や関節モーメントなど歩行パターンに影響す る因子が多くあることは疑いのないことである。今後, 膝・股関節の筋活動の測定を加え, 三次元動作分析装置 を併用し，歩行パターンの分析を詳細に進めていきた い.

\section{引用文献}

1) de Quervain IA, Simon SR, Leurgans S, et al.: Gait pattern in the recovery period after stroke. J Bone Joint Surg Am, 1996, 78(10): 1506-1514.

2) Knutsson E, Richards C: Different types of disturbed motor control in gait of hemiparetic patients. Brain, 1979, 102(2): 405-430.

3) Sandra JO, Richards C: Hemiparetic gait following stroke. Part1: Characteristics. Gait Posture, 1996, 4(2): 136-148.

4) Mulroy S, Gronley J, Weiss W, et al.: Use of cluster analysis for gait pattern classification of patients in the early and late recovery phases following stroke. Gait Posture, 2003, 18(1): 114-125.

5) Lamontagne A, Richards C, Malouin F, et al.: Coactivation during gait as adaptive behavior after stroke. J Electoromyogr Kinesiol, 2000, 10(6): 407-415.

6) The SENIAM project: SEMG sensors. http://www.seniam. org/lowerleg_location.htm（閲覧日2014年3月 29日）

7) 中村隆一, 斎藤 宏, 長崎 宏: 基礎運動学第 6 版 : 医歯 薬出版, 東京, 2003, p382.

8) 大畑光司：Gait Solution付短下肢装具による脳卒中片麻 瘒の運動療法とその効果. PT ジャーナル，2011，45(3): 217-224.

9) Lamontagne A, Malouin F, Richards CL: Mechanisms of disturbed motor control in ankle weakness during gait after stroke, Gait Posture. 2002, 15(3): 244-255.

10) Nadeau S, Gravel D, Arsenault AB, et al.: Plantarflexor weakness as a limiting factor of gait speed in stroke subjects and the compensating role of hip flexors. Clin Biomech. 1999, 14(2): 125-135.

11) Perry J, Burnfield JM: Gait analysis. Slack, California, 2010, pp167-278. 